\title{
REQUIREMENTS FOR THE CRISIS MANAGER FUNCTION - SURVEY FROM CZECH BUSINESSES
}

\author{
[Požadavky na funkci krizového manažera - průzkum z českých podniků] \\ Marie Mikušová ${ }^{1}$ \\ ${ }^{1}$ Technical University of Ostrava, Economics Faculty, Sokolská 33, 70121 Ostrava \\ Email:marie.mikusova@vsb.cz.
}

\begin{abstract}
The aim of this article is to present skills and abilities of a crisis manager, which managers of small businesses identified, and the evaluation of their significance for the performance of this function. A similar model or summary of these skills and abilities has not been identified in both Czech and foreign literature. For its creation it was necessary to carry out survey. A pilot survey was conducted on a sample of 350 respondents. An overview of abilities and skills was generated based on brainwriting. A mind map depicts generated proposals into two levels. To determine the significance of the identified skills the Saaty's method was used. Skills and abilities are concentrated in three groups - managerial, interpersonal and technical. Also different attributes of individual skills according to the level of their development were established. The model of required skills and abilities was created in cooperation with respondents and experts from crisis management. It can be a useful tool for businesses because this methodological aid is not yet included the in the database of competences.
\end{abstract}

Keywords: crisis manager, mind map, Saaty’s method, skill, survey.

JEL classification: M19, M21

Doručeno redakci: 1.7.2015; Recenzováno: 14.7.2015; 6.8.2015; Schváleno k publikování: 23.9.2015

\section{Introduction}

Today's crises are varied both in material and phenomenal forms. This fact is reflected in the variability of functions of a crisis manager. There are databases of job descriptions to characterize different functions. However, in Czech is not created a comprehensive, methodical summary of the requirements (skills and abilities) for the crisis manager function. The author also did not found similar model or summary even in foreign literature. This situation has been assessed as a research gap. This lack of methodological requirements has been a challenge for the formulation of a research objective.

The objective of the research (research gap) is to determine what skills and abilities managers and CEOs (chief executive officers) are required for crisis managers along with using the findings for the creation of a model of crisis manager skills and abilities (i.e. competences). To accomplish this objective, it was necessary to carry out empirical research on a representative sample of managers. By inducing literary research and empirical survey skills and abilities, the model of a crisis manager was designed.

The article is structured from the description of a theoretical base, i.e. the definition of relevant terms and the presentation of the research process and the methodology to the processing and the interpretation of data obtained from empirical research.

\section{Theoretical Review}

In order to formulate and interpret research results correctly, it is necessary to define the following terms and give theoretical background. 


\subsection{Skills and Abilities in General}

Abilities are prerequisites for performing the study, professional, theoretical and practical activities of an individual. They are such capacitive personality characteristics that determine the successful execution of human activities, regarding qualitative, quantitative, timing and power terms (Kohoutek, 2002). Abilities cannot be reduced only to the area of the intellect, perception and motor. The concept must be extended to the field of emotional and volitional one. The concept of skill indicates the abilities developed by practice. A skill is the disposition to a correct, quick and effective execution of specific activities using an appropriate method, which is obtained by learning (Kohoutek, 2002). Both terms are part of the term referred to as a competence.

Competences are defined as a set of desirable characteristics, experience, knowledge, abilities, skills, motivation, attitudes and personal qualities for a given activity or position. Competence i.e. skills and abilities can be monitored by various criteria (Vrchota, Kajanová, 2014). According to Hroník (2006) a profile of specific positions is created as a combination of the following categories: managerial competences (skills and abilities that contribute to an excellent performance in the role of a manager, for example conflict resolution, strategic thinking, coaching and more), interpersonal skills (essential for effective communication and building positive relationships with others; empathy, negotiation, presentation skills, etc.) and technical skills (technical skills related to the particular job such as programming abilities, data collection and analysis, budgeting and others). This profile will be used in this article.

\subsection{Skills and Abilities of a Crisis Manager - Literature Review}

A crisis manager must have a strong self-motivational drive, the ability to anticipate and respond to changes dynamically. Assimilating into the role of a crisis manager assumes knowledge of the company and its surroundings, threats and opportunities, possibilities and the resources available for rescuing the company, as well as professional and life experience in managing emergency situations (Frýbert et al. 1995). Monopolizing, not sharing or showing a lack of interest in gaining new knowledge may be proved in extreme situations as very dangerous (Lerbinger, 2012). A crisis manager must know methods and techniques especially in the field of strategic management, project management, change management, process management, time management, conflict management, performance improvement, organizational management, leadership, etc. (Fotr et al. 2006). In addition to the continuous professional development, the knowledge beyond the scope of specialization is being seen as increasingly more important. This includes social skills, planning and decision-making abilities (Lalonde, 2004). Rational and intellectual skills of a crisis manager must also include the management of emotional elements of human behavior (Lalonde and Roux-Dufort, 1982). This involves the ability to create an emotionally supportive environment, calm heated emotions and situations as well as control one's own negative feelings. Whilst collaborating with others a manager should be confident to make his own decisions. A good crisis manager must be creative and have good communication skills (Fink, 2013). Employees follow a manager they can rely on (Topperand and Lagadec, 2013). Mental resilience is also crucial to crisis manager's work (Gmelch, 1982). Wooten and James (2008) point out the importance of the human resources development for the creation of the capacity of the company to manage the activities of crisis management.

\section{Methodology}

Here are described the research process and the methods used in the research. 


\subsection{Research Process}

The article is based on the results of a research conducted in the fall of 2014. Managers or CEOs of small businesses were chosen as the respondents. In accordance with Recommendation 2003/361/EC, the European Commission defines small firm as a firm which has a fewer than 50 employees and a turnover/balance sheet total no greater than $€ 10$ million. The participants were selected randomly from all Czech regions. 350 respondents took part in the pilot survey (Table 1). All participants indicated that their business had been facing a very serious problem but not threatening to the existence of the business itself as yet.

Table 1: The structure of respondents - the most frequented features

\begin{tabular}{ll}
\hline number of respondents & 350 \\
number of employees & $30-40(45 \%)$ \\
annual return & 10 mil. - 20 mil. CZK (360 000 - 720 000 €) \\
& $(58 \%)$ \\
company operates in services/production & services (51\%) \\
company operates in the market... & $10-20$ years (65\%) \\
owner holds a high executive position & $72 \%$ \\
\hline
\end{tabular}

Source: own processing

The competences (skills and abilities) required for the position of a crisis manager were identified using brainwriting. Respondents did not have any theoretical knowledge of crisis management (this was a condition of the participation in the research) and as such were not familiar with the requirements for crisis manager as outlined at the beginning of this article. The respondents electronically submitted a summary of their proposals describing their views on crisis manager skills and abilities. They were asked to aggregate their proposals into three groups: managerial, interpersonal and technical skills and abilities. These groups are considered as the core of skills and abilities, i.e. the first level. Proposals of skills and abilities within each group are considered as a second level. The relevance of each perception/proposal was filtered by a researcher in collaboration with experts from a crisis management branch. For further processing most frequently identified skills and abilities were selected. A list of this aggregated summary was forwarded to all the participants for further comments, additions or exclusions.

The next step is to evaluate the significance of individual skills and abilities in the first and second levels. To fulfill this task, the Saaty's method was used. The pairwise comparison showed the distribution of weights of individual skills and abilities. The obtained values were corrected in cooperation with experts from crisis and human management and transferred to the scale $1-4$. Value of 1 means the slightest importance and value of 4 highest significance of a skill or ability to perform the duties of a crisis manager.

Thus a base of the model of skills and abilities required for the post of a crisis manager was created. For each identified skill or ability five levels were defined and described. Level One presents the lowest requirements on the skill, Level Five means excellent performance of the skill. To complete the model, it was necessary to assign to each skill a required level from a 1 to 5 scale. Even this final part was carried out in cooperation with the respondents.

\subsection{Brainwriting}

Brainwriting is an alternative method to brainstorming that tries to encourage a more uniform participation within a group. This group structured technique is aimed at aiding innovation processes by stimulating creativity (Rohrbach, 1969). Like brainstorming, it is designed to 
generate lots of ideas in a short amount of time. In this research for organizational reasons (different regions, a large number of respondents), the method was modified and an electronic version of the procedure has been applied.

\subsection{Mind Map}

A mind map, sometimes a mental map is a method that helps to systematize and organize information. It also helps to add new information to existing structures. It is a method that supports a two-way process, i.e. getting existing information and experience stored in the brain out, and conversely, "to receive" further information inside - all this by using graphic processing (Buzan and Buzan, 2011). Mind maps work with one central word, which extends while looking for different semantic contents and connotations of the word. It is therefore a kind a grape of information associated with the central word. Mind maps are widely used e.g. in planning or solving problems in project management.

\subsection{Saaty's Method of Determining Weights}

The Saaty's method was used for the treatment of obtained information. In this method, all the pairs are compared and the evaluation criteria are stored in the so-called Saaty matrix $\mathbf{S}=\left(\mathrm{s}_{i j}\right)$, where $\mathrm{i}, \mathrm{j}=1,2, \ldots, \mathrm{n}$. The elements of the matrix are interpreted as the estimates of the proportion of $\mathrm{i}$-th weights $\left(w_{i}\right)$ and the $\mathrm{j}$-th $\left(w_{j}\right)$ criteria (Saaty, 2008):

$$
s_{i j} \approx \frac{w_{i}}{w_{j}} ; i, j=1,2, \ldots, n
$$

$s_{i j} \in\{1 / 9 ; 1 / 8 ; 1 / 7 ; 1 / 6 ; 1 / 5 ; 1 / 4 ; 1 / 3 ; 1 / 2 ; 1 ; 2 ; 3 ; 4 ; 5 ; 6 ; 7 ; 8 ; 9\}$

The comparison between criteria determines whether one criterion is preferred to another but also to what extent. Saaty recommends the use of the nine-point scale, when one point means that the criteria are equally important, up to nine points which means that the first criterion is absolutely (extremely) more important than the second criterion (Saaty and Vargas, 2012). The matrix $\mathbf{S}$ is reciprocal. Before calculating the importance of criteria it is necessary to verify that the specified matrix of paired comparisons is mathematically consistent. The degree of consistency can be assessed in different ways, one of them is the consistency index $(C I)$ defined as follows:

$$
C I=\frac{(\lambda \max -n)}{(\mathrm{n}-1)}
$$

where $\lambda_{\max }$ is the largest eigenvalue of the matrix $\mathbf{S}$ and $n$ is the number of criteria.

Then Saaty proposed to use this index by comparing it with the appropriate one. The appropriate consistency index is called random consistency index $(R I)$. The comparison between consistency index $(C I)$ and random consistency index $(R I)$ is called consistency ratio $(C R)$. The matrix $\mathbf{S}$ is sufficiently consistent if the consistency ratio $C R \leq 0.1$. The calculation of significance from the Saaty's matrix can be done in several ways. One of the simpler frequently used methods is the determination of weights using a weighted geometric average of decision matrix $\mathbf{S}$ rows. By normalizing these averages we obtain an approximate importance of criteria $w_{i}$, by the following formula:

$$
w_{i}=\frac{\left[\Pi_{j=1}^{n} s_{i j}\right]^{\frac{1}{n}}}{\sum_{i=1}^{n}\left[\Pi_{j=1}^{n} s_{i j}\right]^{\frac{1}{n}}} i, j=1,2 \ldots, \mathrm{n}
$$


where $n$ is a number of criteria, $s$ are the elements of the Saaty's matrix $\mathbf{S}$, where $s_{i i}=1, s_{i j}=$ $1 / s_{j i}, s_{i j} \in\{1 / 9 ; 1 / 8 ; 1 / 7 ; 1 / 6 ; 1 / 5 ; 1 / 4 ; 1 / 3 ; 1 / 2 ; 1 ; 2 ; 3 ; 4 ; 5 ; 6 ; 7 ; 8 ; 9\}$.

\section{Results and Comments}

In accordance with the established research objective the results will be presented now.

\subsection{What Skills and Abilities Managers and CEOs Require from Crisis Managers?}

By means of the adaptation of the respondents' comments, the mind map typified relationships and connections between identified skills and abilities were created (Figure 1). Skills and abilities are aggregated into three groups (the first level): managerial, interpersonal and technical ones.

The classification of individual skills and abilities into groups is following (the second level). Managerial skills and abilities are leadership, strategic thinking, focus on results, focus on humans, time management, resilience, problem solving. Interpersonal ones are a sense of belonging, communication, team work, independence, focus on customers. Technical skills and abilities are focused on standards, creative thinking, flexibility, human management, product management, finance management, planning, work organization.

Figure 1: Mind map

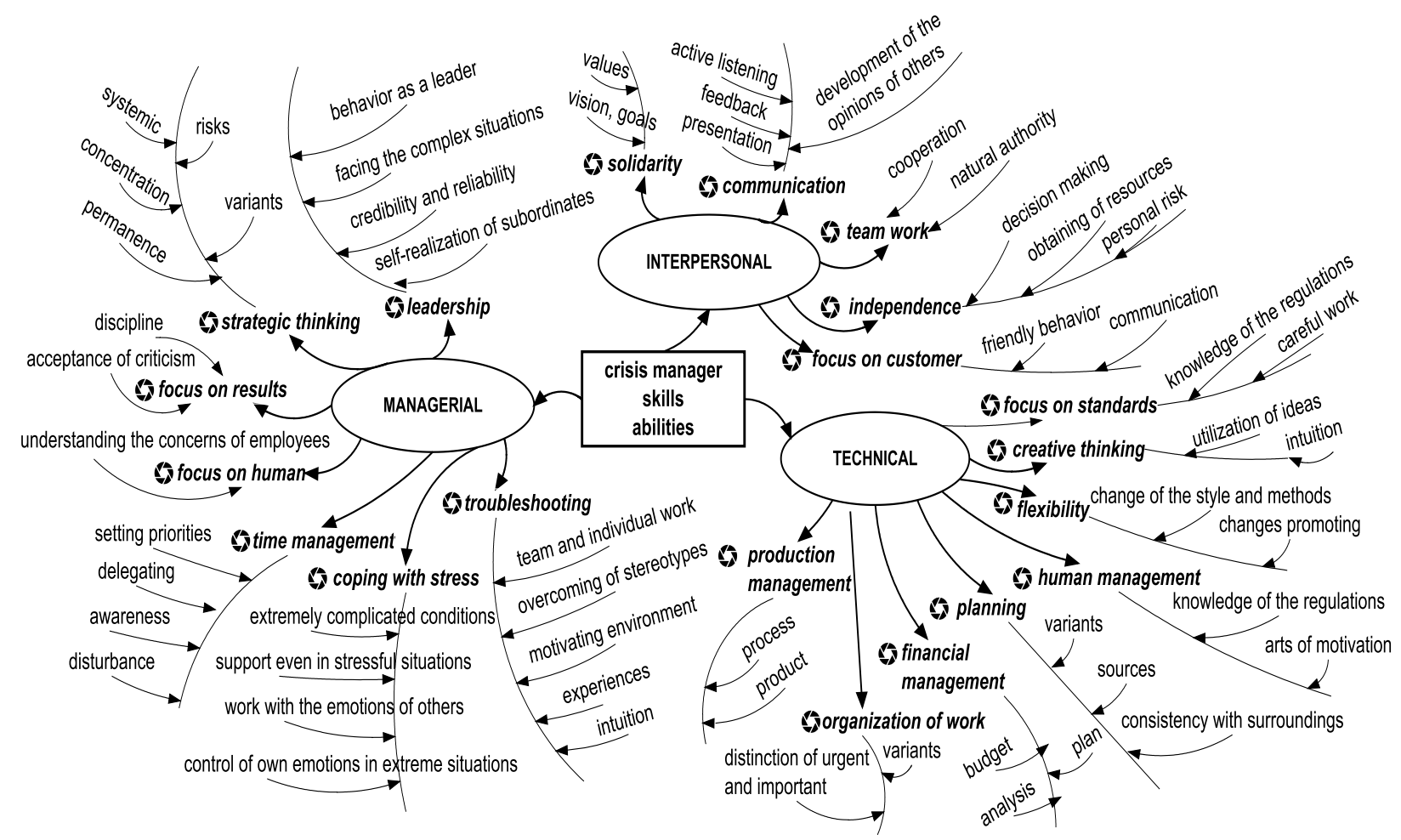

Source: own processing

\subsection{The Evaluation of the Significance of Identified Skills and Abilities}

The respondents assessed groups of skills and abilities at First and Second Level using the Saaty's method to determine which skills and abilities are the most valuable to ensure the successful performance of a crisis manager. Since this is a frequency problem, the median was used for the final matrix creation. 
The following text focuses on the results obtained from these final matrices presented in the graphical form, too.

\subsubsection{The Paired Comparisons of the First Level of Skills and Abilities}

The Saaty's final matrix is presented in Table 2.

Table 2: First Level of skills and abilities - paired comparisons

\begin{tabular}{|c|c|c|c|c|c|c|c|}
\hline matrix $\mathrm{S}$ & managerial & interpersonal & technical & geomean & weight $w$ & $S \times w$ & $(S \times w)_{i} / w_{i}$ \\
\hline managerial & 1 & 4 & 9 & 3.3019 & 70.09 & 2.1782 & 3.1078 \\
\hline interpersonal & $1 / 4$ & 1 & 6 & 1.1447 & 24.30 & 0.7551 & 3.1074 \\
\hline technical & $1 / 9$ & $1 / 6$ & 1 & 0.2646 & 5.61 & 0.1745 & 3.1049 \\
\hline & & & & 4.7112 & 100.00 & $\lambda_{\max }=$ & 3.1067 \\
\hline & & & & $R I=$ & 0.580 & $C I=$ & 0.0539 \\
\hline & & & & $\mathrm{N}=$ & 3 & $C R=$ & 0.0930 \\
\hline
\end{tabular}

Notes: geomean $=$ geometric mean, $\lambda_{\max }=$ the largest eigenvalue of the matrix $S, R I=$ random index, $N=$ number of criteria, $C I=$ consistency index, $C R=$ consistency ratio $(\leq 0.1), w=$ Saaty's weight vector, $w_{i}=i$-th element of vector $w$ (weight of $i$-th criteria in \%)

Source: own processing

It is evident that respondents highly appreciated managerial skills and abilities (that contribute to outstanding performance in the role of a manager), which reached the level of significance of $0.7(70.09 \%)$. What is striking is the low evaluation of technical competences (i.e. the skills related to specific job) with a weight of $0.056(5.61 \%)$.

\subsubsection{The Paired Comparison of the Second Level of Skills and Abilities}

Skills and abilities at the Second Level are captured in the Saaty's final matrices in Appendix 1 and figures (Figure 2, 3, 4).

Figure 2: Managerial skills and abilities

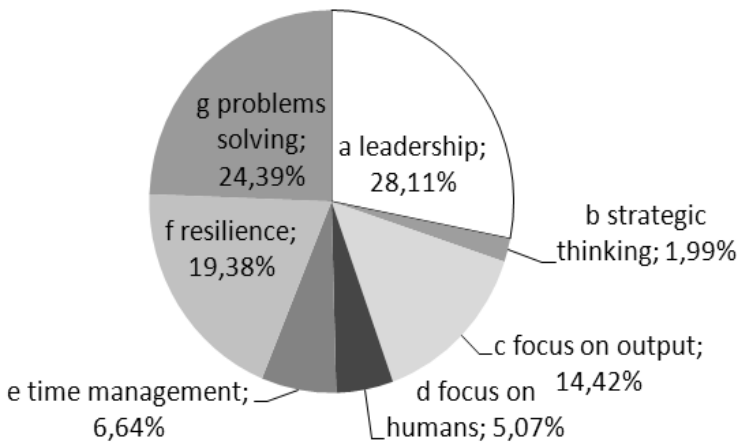

Source: own processing

The respondents were in agreement that a charismatic leader is essential at times of a crisis, as well as their problem solving skills (Figure 2). At the same time the respondents were aware of the need for psychological resilience of a crisis manager. Strategic thinking, on the other hand, was rated very low. Apparently this is due to the fact that in times of a crisis it is necessary to be able to make short-term decisions promptly. However, even at such times, it is dangerous to underestimate or ignore long-term strategic decisions. 
Figure 3: Interpersonal skills and abilities

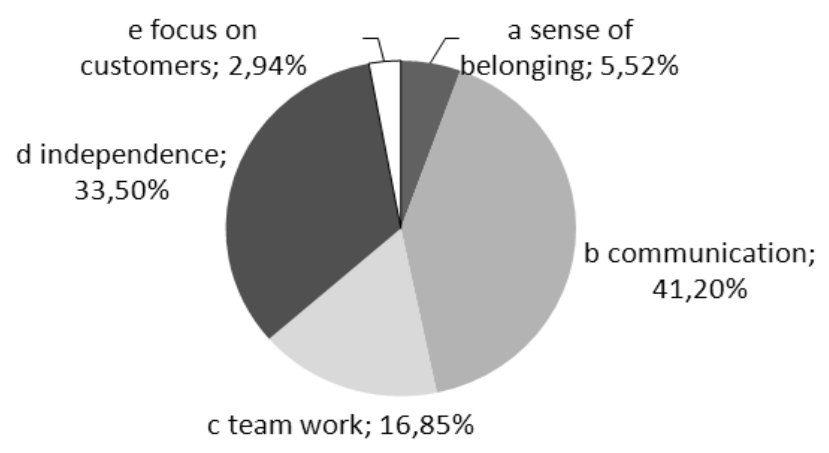

Source: own processing

In order to communicate one cannot be afraid to accept and take responsibility for independent decisions as pointed out by the respondents as one of the most important interpersonal skills (Figure 3). They also recognized that saving the company is not in the hands of individuals but in those of the whole team. A crisis manager must be able and willing to create a team of experts in order to rescue the company and utilize and support their abilities.

Figure 4: Technical skills and abilities

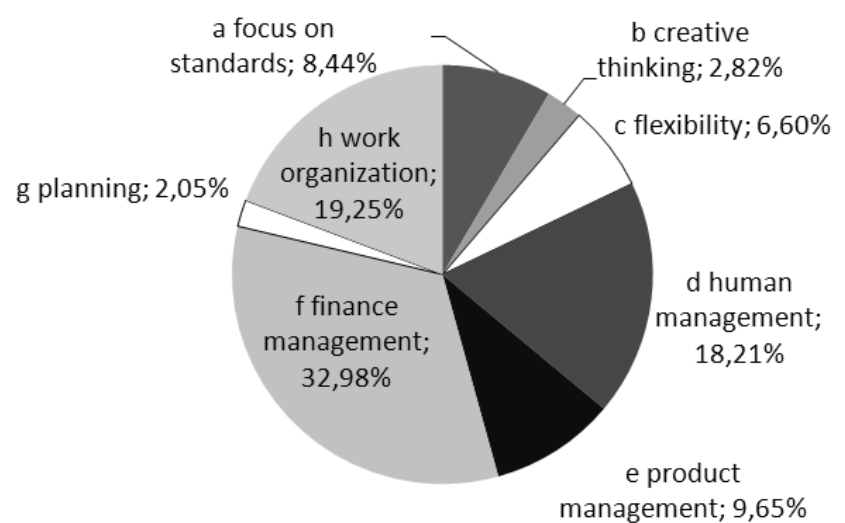

Source: own processing

Financial management is clearly the first one among technical skills (Figure 4). The human factor, i.e. human management and organization of workloads is in the second place of importance. The little importance attributed to planning could have stemmed from the same reason as the evaluation of strategic thinking in the group of managerial competences. The low evaluation of creative approach capabilities is surprising, however. It is as if the owners focused on responding to the situation and its development (flexibility) but not looking forward in order to creatively prevent such situations from happening.

\subsubsection{The Comparison of Significance}

On the back of further discussions with the respondents and experts in the field of management the ranking of some skills were corrected.

Therefore it can be argued that, although respondents have not theoretical knowledge, their experiences and intuition, which are presented in the proposals in the mind map do not deviated from already formulated and tested requirements. 
However, differences in how the significance of individual skills and abilities is assessed by managers and experts in the field of crisis management are evident (Figure 5). Respondents rate the importance of individual skills and abilities as a percentage using the Saaty's method (previous chapter). The next step was to determine the degree of importance that individual skills and abilities have for the effective performance of the crisis manager job (with the cooperation with experts). An ordinal scale was used. The values obtained from Saaty's method were converted using an expert estimation into four levels, where grade one means a high marginal significance in order to achieve an excellent performance level and grade four indicates that the skill or ability is crucial for achieving excellent level of performance (see Appendix 2, column $I$ - importance of skills and abilities).

Figure 5: The comparison of significance

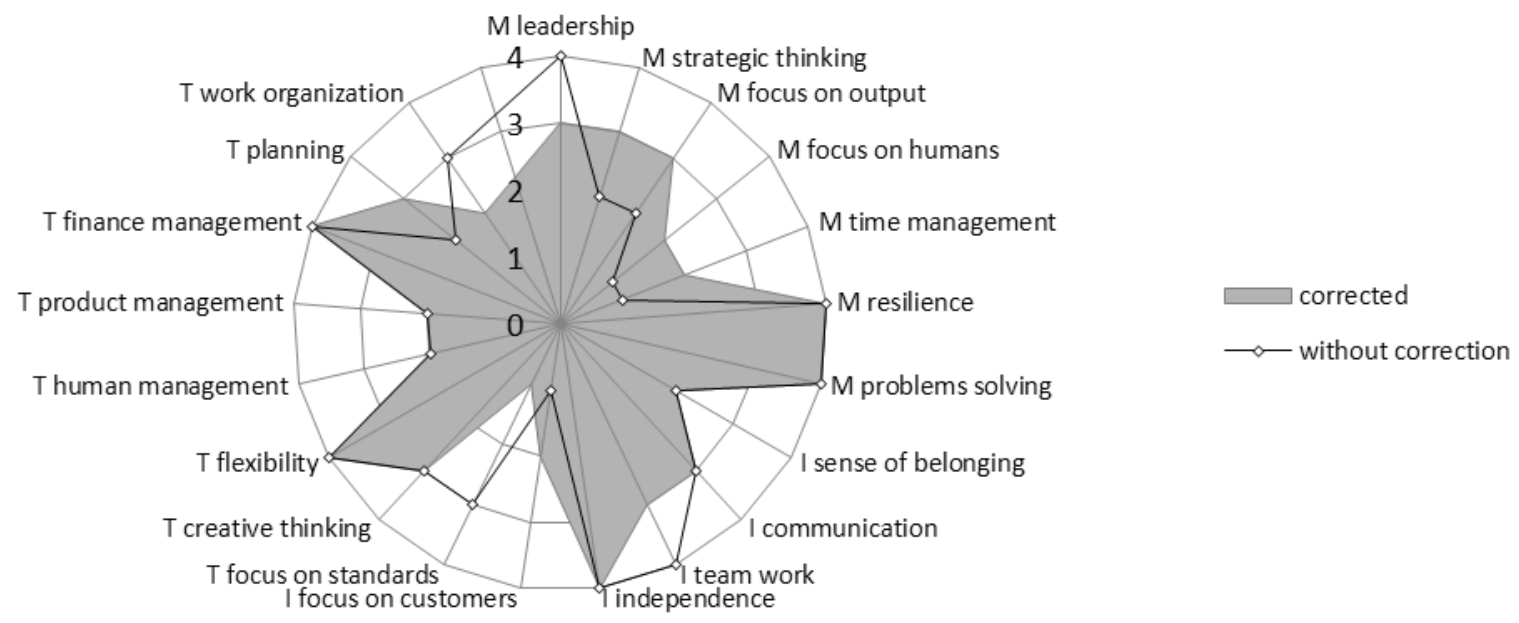

without correction $=$ assessment of business managers

corrected $=$ assessment of crisis management experts

$\mathrm{M}=$ managerial skills and abilities, $\mathrm{I}=$ interpersonal skills and abilities, $\mathrm{T}=$ technical skills and abilities

Source: own processing

Both groups agreed in assessing: focus on results, focus on humans, time management, problems solving, a sense of belonging, team work, independence, product management and finance management, which is almost the half of issues.

Managers significantly underestimate the significance of technical skills. The only exception is the knowledge of "financial management". The second big difference is in managerial skill "strategic management" that managers also underestimate. Other differences in the assessment are not so extreme.

Corrected values (i.e. the assessment of crisis management experts) were used for the model of skills and abilities creation.

Evaluated skills and abilities can be sorted into clusters. Clusters will be created according to the grades of skills and abilities significance (Figure 6). 
Figure 6: Clusters of skills and abilities

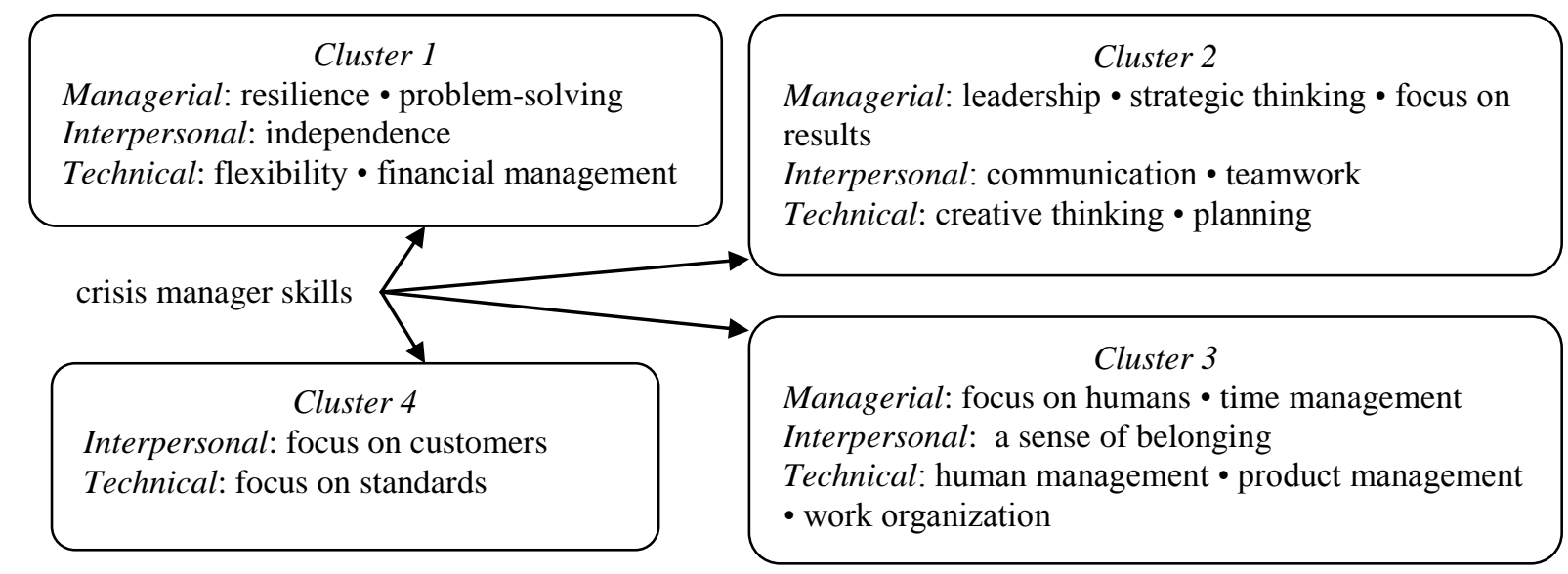

Source: own processing

Cluster 1 (crucial to the excellent performance of a crisis manager): 4 grades

Cluster 2 (very important for the excellent performance of a crisis manager): 3 grades

Cluster 3 (less significant for the excellent performance of a crisis manager): 2 grades

Cluster 4 (marginal significance for the excellent performance): 1 grade

\section{The Completion of the Model of Skills and Abilities}

The frame of model is shown in Table 3.

Table 3: Model of skills and abilities (competencies)

\begin{tabular}{|c|c|c|c|c|}
\hline \multicolumn{5}{|c|}{ Skills and abilities (competencies) of a crisis manager } \\
\hline \multirow{\Xi}{*}{} & $\begin{array}{c}\text { Skills and } \\
\text { abilities }\end{array}$ & Examples of observable behavior & $\begin{array}{c}\text { T-target } \\
\text { value } \\
(1-5)\end{array}$ & $\begin{array}{c}\text { I- importance } \\
\text { of skill or } \\
\text { ability } \\
(1-4)\end{array}$ \\
\hline
\end{tabular}

Source: own processing

Its progressive creation is described in previous chapters.

For the completion of the model the definition of the levels of individual skills has been followed. It means describing the properties of skills based on the level of personal development. Five Levels (ordinal scale) have been determined for the purpose of this research. Level One characterizes a weak level of skill or ability, Level Three - middle level, Level Five characterizes an excellent value (see Appendix 3). Also, there have been assigned target values to the individual skills. These indicate the expected characteristics of skills or abilities for the job position. The highest level is not always required.

The scale of the importance of skills, levels of skill and target values have been recommended on the basis of consultations with the respondents and experts in the field of crisis and human management (see Appendix 1, column $T$ - target value).

The proposed model is shown in Appendix 2. Due to the extensiveness of the model here are just examples of observable behaviors for selected skills and abilities. The model is a very 
abbreviated in this article. In Appendix 3 an example of the description of the levels for the skills "communication" is presented.

\section{Conclusions}

The presented crisis manager model is based on the survey of participants' actual requirements and emphasizes internal qualities of individuals as a result of their personal development. Based on the created mind maps it can be stated that the requirements identified by the managers will be in line with already formulated and presented requirements in professional literature. At the same time, it is evident the underestimation of the importance of some key skills.

Managerial skills and abilities as a group on the First Level are the most valued. Regarding the skills of the Second Level managers most appreciated psychical resistance of a crisis manager, his ability to solve problems, ability to independently decide, flexibly adapt to the situation and to master financial management. Compliance with standards and respect for the customer within the identified requirements for a crisis manager are considered the least important for his excellent performance.

Suggested model fills a gap in the system of a database of competences for various job positions. It also may become a useful tool especially for managers of small businesses but not only for them.

\section{Acknowledgment}

This paper is supported by the Student Grant Competition of the Faculty of Economics, VSBTechnical University of Ostrava, project registration number SP2015/93 and by European Social Fund (OPVK project CZ.1.07/2.3.00/20.0296).

\section{References}

[1] BUZAN, T. and B. BUZAN, 1996. The Mind Map Book: How to Use Radiant Thinking to Maximize Your Brain's. New York: Plume. ISBN 13 978-0452273221.

[2] Commission Recommendation 2003/361/EC [online]. [Accessed 12th June 2015]. Available at: http://www.google.cz/url?sa=t\&rct=j\&q=\&esrc=s\&source=web\&cd=2\& ved $=0 \mathrm{CCoQFjAB \& url=http} \% 3 \mathrm{~A} \% 2 \mathrm{~F} \% 2 \mathrm{Fec}$.europa.eu $\% 2 \mathrm{Fenterprise} \% 2 \mathrm{Fpolicies} \% 2 \mathrm{Fs}$ me\%2Ffiles\%2Fsme_definition\%2Fsme_user_guide_en.pdf\&ei=nt2HVcqGKca7ygO6q wc\&usg=AFQjCNEUgKVHiHsNkaUwsKf5O-cGn82HdA

[3] FINK, S., 2013. Crisis Communications: The Definitive Guide to Managing the Message. 3rd ed. London: McGraw-Hill. ISBN 13 978-0071799218.

[4] FOTR, J., L. ŠVECOVÁ, J. DĚDINA, H. HRŮZOVÁ and J. RICHTER, 2006. Manažerské rozhodování: postupy, metody a nástroje. Praha: Ekopress. ISBN 978-8086929-59-0.

[5] FRÝBERT, B. et al., 1995. Jak transformovat podnik? Ostrava: Montanex. ISBN 8085780-25-9.

[6] GMELCH, W. H., 1982. Beyond Stress to Effective Management. New York: Wiley. ISBN 13 978-0471096597.

[7] HRONÍK, F., 2006. Hodnoceni pracovníků. Praha: Grada. ISBN 80-247-1458-2.

[8] KOHOUTEK, R., 2002. Základy užité psychologie. Brno: CERM. ISBN 80-7204-200-9. 
[9] LALONDE, C., 2004. In search of archetypes in crisis management. Journal of Contingencies \& Crisis Management, 12(2), 76-88. ISSN 1468-5973.

[10] LALONDE, C. and C. ROUX-DUFORT, 2013. Challenges in Teaching Crisis Management. Connecting Theories, Skills, and Reflexivity. Journal of Management Education, 37(1), 21-50. ISSN 1552-6658.

[11] LERBINGER, O., 2012. The Crisis Manager. Facing disasters, conflicts, and failures. 2nd ed. London: Routledge. ISBN 13 978-0415892315.

[12] ROHRBACH, B., 1969. Kreativ nach Regeln. Methods 635. Absatzwirtschaft, 19(12), 73-76. ISSN 0001-3374.

[13] SAATY, T. L., 2008. Decision making with the analytic hierarchy process. Int. J. Services Sciences, 1(1), 83-98. ISSN 1753-1454.

[14] SAATY, T. L. and L. G. VARGAS, 2012. Models, Methods, Concepts \& Applications of the Analytic Hierarchy Process. 2nd ed. New York: Springer. ISBN 978-1-4614-3597-6.

[15] TOPPER, B. and P. LAGADEC, 2013. Fractal Crises - A New Path for Crisis Theory and Management. Journal of Contingencies \& Crisis Management, 21(1), 4-16. ISSN 1468-5973.

[16] VRCHOTA, J. and A. KAJANOVÁ, 2014. Kompetence manažerů v neziskovém sektoru. Acta academica karviniensia, 2014(4), 108-114. ISSN 1212-415X.

[17] WOOTEN, L. P. and E. H. JAMES, 2008. Linking crisis management and leadership competencies: The role of human resource development. Advances in Developing Human Resources, 10(3), 352-79. ISSN 1523-4223. 
Appendix 1: Paired comparisons of the Second Level of skills and abilities

Managerial skills and abilities - paired comparisons

\begin{tabular}{|c|c|c|c|c|c|c|c|c|c|c|c|}
\hline$S$ & $\mathrm{a}$ & $\mathrm{b}$ & $\mathrm{c}$ & $\mathrm{d}$ & $\mathrm{e}$ & $\mathrm{f}$ & $\mathrm{g}$ & geomean & weight $w$ & $S \times w$ & $(S \times w)_{i} / w_{i}$ \\
\hline $\mathrm{a}$ & 1 & 9 & 4 & 5 & 4 & $1 / 2$ & 3 & 2.7124 & 28.11 & 2.3848 & 8.4843 \\
\hline b & $1 / 9$ & 1 & $1 / 9$ & $1 / 5$ & $1 / 4$ & $1 / 8$ & $1 / 8$ & 0.1921 & 1.99 & 0.1486 & 7.4662 \\
\hline $\mathrm{c}$ & $1 / 4$ & 9 & 1 & 3 & 3 & 1 & $1 / 2$ & 1.3920 & 14.42 & 1.0606 & 7.3529 \\
\hline d & $1 / 5$ & 5 & $1 / 3$ & 1 & $1 / 2$ & $1 / 5$ & $1 / 5$ & 0.4888 & 5.07 & 0.3752 & 7.4077 \\
\hline $\mathrm{e}$ & $1 / 4$ & 4 & $1 / 3$ & 2 & 1 & $1 / 3$ & $1 / 5$ & 0.6410 & 6.64 & 0.4791 & 7.2126 \\
\hline $\mathrm{f}$ & 2 & 8 & 1 & 5 & 3 & 1 & $1 / 3$ & 1.8701 & 19.38 & 1.5933 & 8.2213 \\
\hline g & $1 / 3$ & 8 & 2 & 5 & 5 & 3 & 1 & 2.3535 & 24.39 & 1.9521 & 8.0038 \\
\hline \multicolumn{3}{|c|}{$\begin{array}{l}\text { a leadership } \\
\text { b strategic thinkir } \\
\text { c focus on output } \\
\text { d focus on humar }\end{array}$} & \multicolumn{5}{|c|}{$\begin{array}{l}\text { e time management } \\
\text { f resilience } \\
\mathrm{g} \text { problems solving }\end{array}$} & $\begin{array}{l}9.6498 \\
R I= \\
N=\end{array}$ & $\begin{array}{c}100.00 \\
1.320 \\
7\end{array}$ & $\begin{aligned} \lambda_{\max } & = \\
C I & = \\
C R & =\end{aligned}$ & $\begin{array}{c}7.7355 \\
0.1226 \\
0.0929\end{array}$ \\
\hline
\end{tabular}

Interpersonal skills and abilities - paired comparisons

\begin{tabular}{|c|c|c|c|c|c|c|c|c|c|}
\hline$S$ & $\mathrm{a}$ & $\mathrm{b}$ & $\mathrm{c}$ & $\mathrm{d}$ & $\mathrm{e}$ & geomean & weight $w$ & $S \times w$ & $(S \times w)_{i} / w_{i}$ \\
\hline $\mathrm{a}$ & 1 & $1 / 7$ & $1 / 6$ & $1 / 7$ & 4 & 0.4234 & 5.52 & 0.3074 & 5.5689 \\
\hline b & 7 & 1 & 5 & 1 & 9 & 3.1598 & 41.20 & 2.2399 & 5.4368 \\
\hline $\mathrm{c}$ & 6 & $1 / 5$ & 1 & $1 / 2$ & 6 & 1.2920 & 16.85 & 0.9257 & 5.4954 \\
\hline d & 7 & 1 & 2 & 1 & 8 & 2.5695 & 33.50 & 1.7052 & 5.0899 \\
\hline $\mathrm{e}$ & $1 / 4$ & $1 / 9$ & $1 / 6$ & $1 / 8$ & 1 & 0.2252 & 2.94 & 0.1589 & 5.4122 \\
\hline \multirow{2}{*}{\multicolumn{3}{|c|}{$\begin{array}{l}\text { a sense of belonging } \\
\text { b communication }\end{array}$}} & \multicolumn{3}{|c|}{ d independence } & 7.6698 & 100.00 & $\lambda_{\max }=$ & 5.4006 \\
\hline & & & focus & uston & & $R I=$ & 1.120 & $C I=$ & 0.1002 \\
\hline \multicolumn{3}{|c|}{ c team work } & & & & $N=$ & 5 & $C R=$ & 0.0894 \\
\hline
\end{tabular}

Technical skills and abilities - paired comparisons

\begin{tabular}{|c|c|c|c|c|c|c|c|c|c|c|c|c|}
\hline $\mathrm{S}$ & $\mathrm{a}$ & $\mathrm{b}$ & $\mathrm{c}$ & $\mathrm{d}$ & $\mathrm{e}$ & $\mathrm{f}$ & $\mathrm{g}$ & $\mathrm{h}$ & geomean & weight $\mathrm{w}$ & $S \times w$ & $(S \times w)_{i} / w_{i}$ \\
\hline $\mathrm{a}$ & 1 & 3 & 2 & $1 / 2$ & 3 & $1 / 9$ & 5 & $1 / 7$ & 0.9588 & 8.44 & 0.8484 & 10.0532 \\
\hline $\mathrm{b}$ & $1 / 3$ & 1 & $1 / 4$ & $1 / 7$ & $1 / 5$ & $1 / 8$ & 3 & $1 / 8$ & 0.3206 & 2.82 & 0.2451 & 8.6855 \\
\hline $\mathrm{c}$ & $1 / 2$ & 4 & 1 & $1 / 4$ & $1 / 2$ & $1 / 5$ & 4 & $1 / 2$ & 0.7499 & 6.60 & 0.5592 & 8.4726 \\
\hline $\mathrm{d}$ & 2 & 7 & 4 & 1 & 2 & $1 / 2$ & 6 & 1 & 2.0692 & 18.21 & 1.4860 & 8.1597 \\
\hline $\mathrm{e}$ & $1 / 3$ & 5 & 2 & $1 / 2$ & 1 & $1 / 2$ & 5 & $1 / 2$ & 1.0961 & 9.65 & 0.8526 & 8.8380 \\
\hline $\mathrm{f}$ & 9 & 8 & 5 & 2 & 2 & 1 & 9 & 3 & 3.7473 & 32.98 & 2.9645 & 8.9885 \\
\hline $\mathrm{g}$ & $1 / 5$ & $1 / 3$ & $1 / 4$ & $1 / 6$ & $1 / 5$ & $1 / 9$ & 1 & $1 / 7$ & 0.2334 & 2.05 & 0.1771 & 8.6205 \\
\hline $\mathrm{h}$ & 7 & 8 & 2 & 1 & 2 & $1 / 3$ & 7 & 1 & 2.1866 & 19.25 & 1.7697 & 9.1956 \\
\hline \multicolumn{4}{|c|}{ focus on standard } & \multicolumn{5}{|c|}{ e product management } & 11.3619 & 100.00 & $\lambda_{\max }=$ & 8.8767 \\
\hline \multirow{2}{*}{\multicolumn{4}{|c|}{ inkir }} & \multirow{2}{*}{\multicolumn{5}{|c|}{$\begin{array}{l}\text { f finance management } \\
\text { g planning }\end{array}$}} & $R I=$ & 1.410 & $C I=$ & 0.1252 \\
\hline & & & & & & & & & $N=$ & 8 & $C R=$ & 0.0888 \\
\hline
\end{tabular}

$\mathrm{d}$ human management $\mathrm{h}$ work organization

Notes: geomean $=$ geometric mean, $\lambda_{\max }=$ the largest eigenvalue of the matrix $\mathbf{S}, R I=$ random index, $N=$ number of criteria, $C I=$ consistency index, $C R=$ consistency ratio $(\leq 0.1), w=$ Saaty's weight vector, $w_{i}=\mathrm{i}$-th element of vector $w$ (weight of i-th criteria in \%)

Source: own processing 
Appendix 2: Model of skills and abilities for the position of a crisis manager (greatly abbreviated)

\begin{tabular}{|c|c|c|c|c|}
\hline \multicolumn{5}{|c|}{ Skills and abilities (competencies) of a crisis manager } \\
\hline \multicolumn{2}{|c|}{ Skills and abilities } & Examples of observable behavior & $\mathrm{T}$ & I \\
\hline \multirow{7}{*}{ 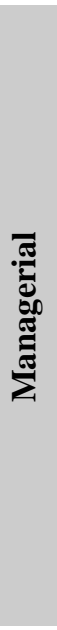 } & Leadership & & 4 & 3 \\
\hline & Strategic thinking & & 3 & 3 \\
\hline & Focus on results & & 3 & 3 \\
\hline & Focus on humans & - understands colleagues' concerns $\bullet$ well-being at the workplace is crucial & 2 & 2 \\
\hline & $\begin{array}{l}\text { Time } \\
\text { management }\end{array}$ & & 2 & 2 \\
\hline & Resilience & $\begin{array}{l}\bullet \text { consistent performer even under extremely difficult conditions } \bullet \text { has } \\
\text { realistic approach to stressful situations } \bullet \text { able to induce changes in order to } \\
\text { achieve a more effective result } \bullet \text { able to overcome obstacles by analyzing } \\
\text { situations, looking for alternatives and choosing the best solution } \bullet \text { provides } \\
\text { support to others in stressful situations } \bullet \text { able to control own emotions even } \\
\text { in highly stressful situations and handle the emotions of others } \bullet \text { self- } \\
\text { confident }\end{array}$ & 5 & 4 \\
\hline & Problem solving & & 5 & 4 \\
\hline \multirow{5}{*}{ 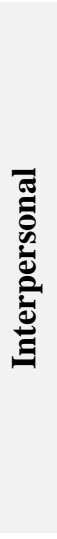 } & $\begin{array}{l}\text { A sense of } \\
\text { belonging }\end{array}$ & $\begin{array}{l}\text { - understands and supports the values and culture of the organization and } \\
\text { takes ownership for it } \bullet \text { familiar with the vision and strategy of the } \\
\text { organization }\end{array}$ & 2 & 2 \\
\hline & Communication & $\begin{array}{l}- \text { formulating ideas in written and oral form is very good } \bullet \text { actively listens } \\
\text { to others } \bullet \text { reasonable assertiveness is natural for him } \bullet \text { able to present } \\
\text { before the group } \bullet \text { able to open the communication } \bullet \text { supports } \\
\text { communication of others } \bullet \text { accepts and develops the opinions of others } \\
\text { able to cause a constructive conflict } \bullet \text { requires feedback }\end{array}$ & 4 & 3 \\
\hline & Team work & & 5 & 3 \\
\hline & Independence & & 5 & 4 \\
\hline & $\begin{array}{l}\text { Focus on } \\
\text { customers }\end{array}$ & & 2 & 1 \\
\hline \multirow{8}{*}{ 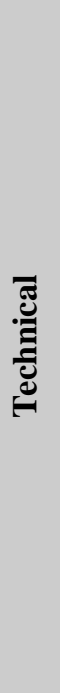 } & $\begin{array}{l}\text { Focus on } \\
\text { standards }\end{array}$ & $\begin{array}{l}\text { - familiar with the company's rules } \bullet \text { attention to detail with final results } \\
\text { error free }\end{array}$ & 1 & 1 \\
\hline & Creative thinking & & 5 & 3 \\
\hline & Flexibility & & 5 & 4 \\
\hline & $\begin{array}{l}\text { Human } \\
\text { management }\end{array}$ & & 3 & 2 \\
\hline & $\begin{array}{l}\text { Product } \\
\text { management }\end{array}$ & & 2 & 5 \\
\hline & $\begin{array}{l}\text { Finance } \\
\text { management }\end{array}$ & $\begin{array}{l}\text { - able to control budget spending via keeping to the plan } \bullet \text { comes up with } \\
\text { proposals to achieve higher profitability } \bullet \text { suggests measures and } \\
\text { adjustments to the budget in case of deviation } \bullet \text { analyses costs and its } \\
\text { impact on all parts of the business and financial plans } \bullet \text { discusses } \\
\text { suggestions and changes in plans with management }\end{array}$ & 5 & 4 \\
\hline & Planning & & 3 & 3 \\
\hline & $\begin{array}{l}\text { Work } \\
\text { organization }\end{array}$ & & 2 & 2 \\
\hline
\end{tabular}

Source: own processing 


\section{Appendix 3: Description of levels of selected skill}

Skill or ability: Interpersonal - Communication - description of levels 1-5

1 - ideas formulating, especially written, is difficult for him $\bullet$ does not listen to others $\bullet$ passes the information to others only at request $\bullet$ 's response to unexpected situations cannot be predicted

- in normal situations, formulates ideas clearly and understandably in both oral and written forms $\bullet$ listens

2 to others without much difficulty $\bullet$ shares information $\bullet$ responds adequately to the situation $\bullet$ communication is not always convincing

$3 \bullet$ formulates ideas clearly and understandably in both oral and written forms $\bullet$ listens to others $\bullet$ assertively responding to the situation $\bullet$ can attract others with his speech $\bullet$ tolerates the opinions of others

- formulating ideas in written and oral forms is very good • actively listens to others $\bullet$ reasonable

4 assertiveness is natural for him $\bullet$ able to present before the group $\bullet$ able to open the communication $\bullet$ supports the communication of others $\bullet$ accepts and develops the opinions of others $\bullet$ able to cause a constructive conflict $\bullet$ requires feedback

- formulating ideas in written and oral forms is excellent $\bullet$ practices active listening, without exception, in

5 all circumstances $\bullet$ able to present in the big forum and able to convince others $\bullet$ able to get real opinions from others and interact with them $\bullet$ able to benefit from a constructive conflict $\bullet$ able to work with feedback $\bullet$ communicates with other cultures

Source: own processing 